\title{
Study of acid-base indicator property of flowers of Ipomoea biloba
}

\author{
Sajin Kattuvilakam Abbas \\ Rajiv Gandhi Institute of Pharmacy, Trikaripur, Kasargod (dt), Kerala, India
}

\begin{abstract}
Indicators help to determine the equivalence point in acid - base titrations (neutralization titrations). They show sharp color change with respect to change in $\mathrm{pH}$. Commonly used indicators for neutralization titrations are synthetic in nature. They are found to posses hazardous effects in human body. The highly colored pigments obtained from plants are found to exhibit color changes with variation of $\mathrm{pH}$. A study has been done to investigate the indicator activity of aqueous extract of flower pigments and compared with that of already existing synthetic indicators. Pigments were extracted using hot water and a definite volume was added which gave accurate and reliable results for all the four different types of neutralization titrations - strong acid against strong base, strong acid against a weak base, weak acid against strong base and weak acid against weak base. The work proved to be acceptable in introducing flower pigments as a substitute to the synthetic acid-base indicators.
\end{abstract}

Key Words: Ipomoea, pH indicators, natural pigments, flower pigments, neutralization indicators, phenolphthalein substitutes.

\section{INTRODUCTION}

Ipomoea biloba is a plant of runner variety commonly found in the coastal region throughout the state of Kerala, India (Nadkarni, 1994). The name biloba was coined due to its feature in leaf - the leaf of the plant appears as two lobes, hence the name biloba. The plant is also called as Ipomoea pescaprae (Germplasm resources information network). The flower of the plant is pink colored and the plant belongs to Convolvulaceae family (Khare, 2007). The plant is yearly flowering and easily available in sea shores throughout the Arabian Sea.

Earlier studies done on the synthetic indicators like phenolphthalein, methyl orange helped to identify their toxic and hazardous effects (Dunnick and Hailey, 1996). Moreover, they also posses disadvantages like availability problems and high cost. The study was done with an aim of finding a suitable substitute to replace the synthetic indicators and to bring in the practice of using the flower pigments as indicators in neutralization titrations. The color

\footnotetext{
*Corresponding Author:

Sajin Kattuvilakam Abbas, Lecturer

Rajiv Gandhi Institute of Pharmacy

Trikaripur, Kasargod (dt)

Kerala, India

E-mail:kasajin@gmail.com

Contact No.: 00919037593341
}

change of the pigment with $\mathrm{pH}$ was checked initially using buffer solutions of various $\mathrm{pHs}$, which produced sharp and intense color changes.

\section{METHODOLOGY}

\section{Plant materials}

The collection of fresh flowers of Ipomoea biloba was done from the sea shores of Padne region of Kerala state, India. It was then authenticated at Department of Botany, Centre of Environmental Studies, Kannur University, Kerala.

\section{Reagents}

Reagents of analytical grade were used. Sodium hydroxide, ammonia, hydrochloric acid, ethanoic acid and phenolphthalein were procured from Rajiv Gandhi institute of Pharmacy, Trikaripur. The reagents and volumetric solutions were prepared as per Indian pharmacopeia IP 1996.

\section{Glass wares}

Burettes, pipettes etc were calibrated as per the procedures given in Indian pharmacopeia IP 1996.

\section{Preparation of flower extract}

$1 \mathrm{~g}$ fresh petals of Ipomoea biloba were extracted with warm water for 15 minutes and the aqueous extract separate and were maintained. 
Table 1a. Titration of $\mathrm{HCl}$ against $\mathrm{NaOH}$ using aqueous Ipomoea biloba flower extract indicator.

\begin{tabular}{ccccc}
\hline \multirow{2}{*}{$\begin{array}{c}\text { S1. } \\
\text { No. }\end{array}$} & acid $(\mathbf{m L})$ & \multicolumn{2}{c}{ Burette reading } & \multirow{2}{*}{\begin{tabular}{c} 
Volume of titrant \\
\cline { 3 - 4 }$(\mathbf{m L})$ mean $=\mathbf{E x} / \mathbf{n}$
\end{tabular}} \\
\hline 1 & 10.0 & 0.0 & 9.9 & 9.88 \\
2 & 10.0 & 0.0 & 9.9 & \\
3 & 10.0 & 0.0 & 9.8 & \\
4 & 10.0 & 0.0 & 9.9 & \\
5 & 10.0 & 0.0 & 9.9 & \\
\hline \multicolumn{3}{l}{ End point: Appearance of green color }
\end{tabular}

Table 2a. Titration of $\mathrm{HCl}$ against $\mathrm{NH}_{3}$ using aqueous Ipomoea biloba flower extract indicator.

\begin{tabular}{ccccc}
\hline Sl. & $\begin{array}{c}\text { Vol. of } \\
\text { No. }\end{array}$ acid $(\mathbf{m L})$ & \multicolumn{2}{c}{ Burette reading } & Volume of titrant \\
\cline { 3 - 4 } & Initial $(\mathbf{m L})$ & Final $(\mathbf{m L})$ & $(\mathbf{m L})$ mean $=\mathbf{E x} / \mathbf{n}$ \\
\hline 1 & 10.0 & 0.0 & 9.7 & 9.7 \\
2 & 10.0 & 0.0 & 9.6 & \\
3 & 10.0 & 0.0 & 9.7 & \\
4 & 10.0 & 0.0 & 9.8 & \\
5 & 10.0 & 0.0 & 9.7 & \\
\multicolumn{7}{l}{ End point: Appearance of green color }
\end{tabular}

Table 3a. Titration of Acetic acid against $\mathrm{NaOH}$ using aqueous Ipomoea biloba flower extract indicator.

\begin{tabular}{|c|c|c|c|c|}
\hline \multirow{2}{*}{$\begin{array}{l}\text { Sl. } \\
\text { No. }\end{array}$} & \multirow{2}{*}{$\begin{array}{c}\text { Vol. of } \\
\text { acid (mL) }\end{array}$} & \multicolumn{2}{|c|}{ Burette reading } & \multirow{2}{*}{$\begin{array}{l}\text { Volume of titrant } \\
(\mathrm{mL}) \text { mean }=£ x / n\end{array}$} \\
\hline & & Initial (mL) & Final (mL) & \\
\hline 1 & 10.0 & 0.0 & 9.5 & 9.46 \\
\hline 2 & 10.0 & 0.0 & 9.5 & \\
\hline 3 & 10.0 & 0.0 & 9.3 & \\
\hline 4 & 10.0 & 0.0 & 9.5 & \\
\hline 5 & 10.0 & 0.0 & 9.5 & \\
\hline
\end{tabular}

Table 4a. Titration of Acetic acid against $\mathrm{NaOH}$ using aqueous Ipomoea biloba flower extract indicator.

\begin{tabular}{|c|c|c|c|c|}
\hline \multirow{2}{*}{$\begin{array}{l}\text { Sl. } \\
\text { No. }\end{array}$} & \multirow{2}{*}{$\begin{array}{l}\text { Vol. of } \\
\text { acid (mL) }\end{array}$} & \multicolumn{2}{|c|}{ Burette reading } & \multirow{2}{*}{$\begin{array}{l}\text { Volume of titrant } \\
(\mathrm{mL}) \text { mean }=£ x / n\end{array}$} \\
\hline & & Initial (mL) & Final (mL) & \\
\hline 1 & 10.0 & 0.0 & 9.9 & 10.04 \\
\hline 2 & 10.0 & 0.0 & 10.1 & \\
\hline 3 & 10.0 & 0.0 & 9.9 & \\
\hline 4 & 10.0 & 0.0 & 10.1 & \\
\hline 5 & 10.0 & 0.0 & 10.2 & \\
\hline
\end{tabular}

\section{Experimental procedure}

The petals of Ipomoea biloba were separated and cleaned with distilled water. It was then cut to small pieces and transferred to a clean beaker. $100 \mathrm{ml}$ of distilled water was taken in another beaker and gently warmed and poured to the petals and kept aside for 15 minutes. The extract was then poured carefully to a glass container through a funnel and stored aside separately without exposing to direct sunlight.
Table 1b. Titration of $\mathrm{HCl}$ against $\mathrm{NaOH}$ using Phenolphthalein indicator.

\begin{tabular}{|c|c|c|c|c|}
\hline \multirow{2}{*}{$\begin{array}{l}\text { Sl. } \\
\text { No. }\end{array}$} & \multirow{2}{*}{$\begin{array}{c}\text { Vol. of } \\
\text { acid (mL) }\end{array}$} & \multicolumn{2}{|c|}{ Burette reading } & \multirow{2}{*}{$\begin{array}{l}\text { Volume of titrant } \\
(\mathrm{mL}) \text { mean }=£ x / n\end{array}$} \\
\hline & & Initial (mL) & Final (mL) & \\
\hline 1 & 10.0 & 0.0 & 9.9 & 9.88 \\
\hline 2 & 10.0 & 0.0 & 9.8 & \\
\hline 3 & 10.0 & 0.0 & 9.9 & \\
\hline 4 & 10.0 & 0.0 & 9.9 & \\
\hline 5 & 10.0 & 0.0 & 9.9 & \\
\hline
\end{tabular}

Table 2b. Titration of $\mathrm{HCl}$ against $\mathrm{NH}_{3}$ using Phenolphthalein indicator.

\begin{tabular}{|c|c|c|c|c|}
\hline \multirow{2}{*}{$\begin{array}{l}\text { Sl. } \\
\text { No. }\end{array}$} & \multirow{2}{*}{$\begin{array}{c}\text { Vol. of } \\
\text { acid (mL) }\end{array}$} & \multicolumn{2}{|c|}{ Burette reading } & \multirow{2}{*}{$\begin{array}{l}\text { Volume of titrant } \\
(\mathrm{mL}) \text { mean }=£ x / n\end{array}$} \\
\hline & & Initial (mL) & Final (mL) & \\
\hline 1 & 10.0 & 0.0 & 9.7 & 9.68 \\
\hline 2 & 10.0 & 0.0 & 9.7 & \\
\hline 3 & 10.0 & 0.0 & 9.7 & \\
\hline 4 & 10.0 & 0.0 & 9.6 & \\
\hline 5 & 10.0 & 0.0 & 9.7 & \\
\hline
\end{tabular}

End point: Appearance of pale pink color

Table 3b. Titration of Acetic acid against $\mathrm{NaOH}$ using Phenolphthalein indicator.

\begin{tabular}{|c|c|c|c|c|}
\hline \multirow{2}{*}{$\begin{array}{l}\text { S1. } \\
\text { No. }\end{array}$} & \multirow{2}{*}{$\begin{array}{l}\text { Vol. of } \\
\text { acid (mL) }\end{array}$} & \multicolumn{2}{|c|}{ Burette reading } & \multirow{2}{*}{$\begin{array}{l}\text { Volume of titrant } \\
(\mathrm{mL}) \text { mean }=£ x / n\end{array}$} \\
\hline & & Initial (mL) & Final (mL) & \\
\hline 1 & 10.0 & 0.0 & 9.6 & 9.56 \\
\hline 2 & 10.0 & 0.0 & 9.6 & \\
\hline 3 & 10.0 & 0.0 & 9.6 & \\
\hline 4 & 10.0 & 0.0 & 9.4 & \\
\hline 5 & 10.0 & 0.0 & 9.6 & \\
\hline
\end{tabular}

Table 4b. Titration of Acetic acid against $\mathrm{NH}_{3}$ using Phenolphthalein indicator.

\begin{tabular}{|c|c|c|c|c|}
\hline \multirow{2}{*}{$\begin{array}{l}\text { Sl. } \\
\text { No. }\end{array}$} & \multirow{2}{*}{$\begin{array}{c}\text { Vol. of } \\
\text { acid (mL) }\end{array}$} & \multicolumn{2}{|c|}{ Burette reading } & \multirow{2}{*}{$\begin{array}{l}\text { Volume of titrant } \\
(\mathrm{mL}) \text { mean }=£ x / n\end{array}$} \\
\hline & & Initial (mL) & Final (mL) & \\
\hline 1 & 10.0 & 0.0 & 9.7 & 9.68 \\
\hline 2 & 10.0 & 0.0 & 9.6 & \\
\hline 3 & 10.0 & 0.0 & 9.7 & \\
\hline 4 & 10.0 & 0.0 & 9.7 & \\
\hline 5 & 10.0 & 0.0 & 9.7 & \\
\hline
\end{tabular}

End point: Appearance of pale pink color

\section{Test for color change}

$0.1 \mathrm{ml}$ of the extract was added to $25 \mathrm{ml}$ each of buffer solutions of $\mathrm{pH}$ ranging from 1.2 to 10.2 . The results of the test are listed in table 5.

\section{Titrations}

$0.1 \mathrm{ml}$ of the extract was added as indicator for each titration type- strong acid against strong base, strong acid against weak base. Weak acid against strong base and weak acid against weak base and the trials were repeated 5 times to check the precision. The titrations were again performed using 
Table 5. Color change of indicator with $\mathrm{pH}$ change.

\begin{tabular}{ll}
\hline Buffer solution & Observed colour* \\
\hline Acid - phthalate buffer, pH 3 & Bright red \\
Neutralized phthalate buffer, pH 5 & Light red \\
Phosphate buffer, pH 7 & Pale red \\
Alkaline borate buffer, pH 9 & Dark green \\
Alkaline borate buffer, pH 10 & Dark green \\
\hline${ }^{*}$ On addition of the flower extract indicator
\end{tabular}

phenolphthalein indicator as standard and the results obtained were compared with the results of titrations using plant extract indicator. The results for titrations are depicted in the tables $1 \mathrm{a}$ to $4 \mathrm{~b}$.

\section{RESULTS AND DISCUSSION}

The equivalence point of the titrations using the flower extract either coincided or almost reached close to the equivalence point using the standard indicator, phenolphthalein for all the titrations. In several cases it proved to be more reliable than the standard indicator and gave sharp color change at equivalence point. It was also observed that the extract act reversibly and gave sharp color change in both the directions.

\section{CONCLUSION}

Thus the study helped to realize that the flower pigment of Ipomoea biloba could be effectively used as a substitute to the presently existing indicators owing to the factors like simple preparation, good performance and accurate and precise results.

\section{REFERENCES}

Dunnick, J.K., Hailey, J.R. (1996) Phenolphthalein exposure causes multiple carcinogenic effects in experimental model systems, Cancer Research, 56(21): 4922-4926.

HSDB , Hazardous substance data base, National Library of Medicine, [LINK]

Khare, C.P. (2007) Indian Medicinal Plants: An Illustrated Dictionary, Page 333.

Mendhan, J., Denney R.C., Barnes J.D., Thomas M.J. (2002) Vogel's textbook of quantitative chemical analysis, Pearson education Pvt Ltd, $6^{\text {th }}$ edition, Page 313.

Nadkarni, K.M. (1994) Indian Materia medica, Bombay Popular Prakashan, $3^{\text {rd }}$ edition, Volume 2, Page 550.

Taxon: Ipomoea pes-caprae (L.) R. Br. Germplasm Resources Information Network. Beltsville, Md.: National Genetic Resources Program, Agricultural Research Service, USDA. 9 May 2011. [Accessed on: 27 March 2012] [LINK] 